\title{
From Short Electrospun Nanofibers to Ultralight Aerogels with Tunable Pore Structure
}

\author{
Fabian Deuber ${ }^{\S}$ and Christian Adlhart* \\ §SCS-DSM Award for best poster presentation in Polymers, Colloids \& Interfaces
}

\begin{abstract}
Nanofiber production by electrospinning has made great progress over the past two decades. Recently the research area was revolutionized by a novel post-processing approach. By cutting the endless and intertwined nanofibers into short pieces, it is now possible to reassemble them into interconnected 3D structures. Such highly porous structures are built from dispersed short nanofibers by freeze-casting. This solid templating process controls the structures' ultimate properties and architecture in terms of primary and secondary pores below $5 \mu \mathrm{m}$ and between 10 and $300 \mu \mathrm{m}$, respectively. The objective of this review is to provide insight into this young field of research, in particular highlighting the processing steps, materials and current applications, from scaffolds for tissue engineering, acoustics, sensors and catalyst supports to filtration.
\end{abstract}

Keywords: Aerogel · Electrospinning · Freeze-casting $\cdot$ Short nanofibers $\cdot$ Solid templating

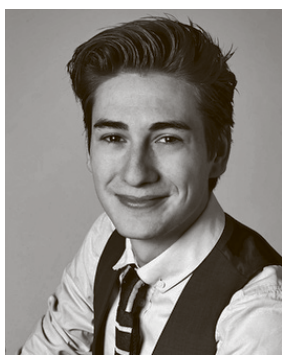

Fabian Deuber, born 1990, studied chemistry at the University of Applied Sciences (ZHAW) following his apprenticeship at Novartis AG. He obtained his bachelor 2012 working on the synthesis and spectroscopic characterization of small chiral molecules together with Prof. Dr. Jürgen Stohner. His master studies under the supervision of Dr. Christian Adlhart focused on novel nanofiber based aerogels to understand fundamental architectureproperty relationships. At $\mathrm{ZHAW}$, he also had the opportunity, to advance nanofiberbased aerogel technology towards applications working with industrial partners. Currently, Fabian Deuber is carrying out his community service at the WSL.
${ }^{*}$ Correspondence: Dr. C. Adlhart Institute of Chemistry and Biotechnology Zurich University of Applied Sciences ZHAW Einsiedlerstrasse 31, CH-8820 Wädenswil E-mail: christian.adlhart@zhaw.ch

\section{Introduction}

Less is more, especially when considering ultralight materials. Due to their characteristics such as high surface area, high porosity, and low apparent density, such materials are of interest for several applications - from catalyst supports, acoustics, thermal insulation, electrode materials and sensors to tissue engineering. ${ }^{[1]} 3 \mathrm{D}$ porous structures are often synthesized using nanoscale building blocks such as nanoparticles, nanotubes, nanorods or recently by using nanofibers. ${ }^{[2]}$ Typically, nanofibers are obtained through electrospinning - an electrostatic fiber drawing process, which has outperformed other nanofiber production technologies in terms of versatility and cost-efficiency. Several approaches exploited the potential of the electrospinning process to build 3D nonwoven scaffolds, ${ }^{[3]}$ including self-assembly, ${ }^{[4]}$ cool drum spinning, ${ }^{[5]}$ or gas expansion. ${ }^{[6]}$ However, these approaches require sophisticated electrospinning devices or post processing, since layer-by-layer deposition dominates fiber production in electrospinning. ${ }^{[7]}$ Moreover, the resulting scaffolds lack the possibility to add scalable pores and often show poor mechanical stability. ${ }^{[8]}$ Recently, Ding and Greiner pioneered a simple way of producing ultralight nanofiber based aerogels or sponges by cutting electrospun membranes into short fiber fragments and subsequently freeze-drying the slurry of these fragments. ${ }^{[2 a, b]}$ The idea of using short electrospun nanofibers to enhance the mechanical stability of composites was already proposed by Reneker. ${ }^{[9]}$ Since then numerous approaches have been investigated to obtain short electrospun nanofibers, either by cutting the fibers with an electric spark or by minutely controlling the spinning parameters. ${ }^{[10]}$ Yet none of them was as straightforward and simple as mechanically cutting the continuous but closely packed fibers in electrospun membranes using a blender or dispersion tool. ${ }^{[11]}$ By separating fiber formation and fiber processing, 3D nanofibrous scaffolds can be produced in a controlled manner without relying on the layer-by-layer dominated deposition character of electrospinning. Ultralight aerogels from short nanofibers as building blocks distinguish themselves by their open and porous architecture with entangled fibers rendering them robust and flexible (Fig. 1). Understanding the underlying solid templating mechanism allowed us to tailor pore shape and pore size of nanofiber-based aerogels. [12] Combining a controllable shaping method with the versatility of fiber production by electrospinning proves outstanding potential for nanofiber-based scaffold production. In the following, we will highlight the fundamental processing steps and applications of 3D nanofiber-based aerogels according to recent advances in this young field of research. ${ }^{[2 a, b, 12,13]}$

\section{Synthesis of Nanofiber-based Aerogels}

Ultralight highly porous aerogels are obtained following four processing steps (Fig. 2). First, continuous nanofibers are 

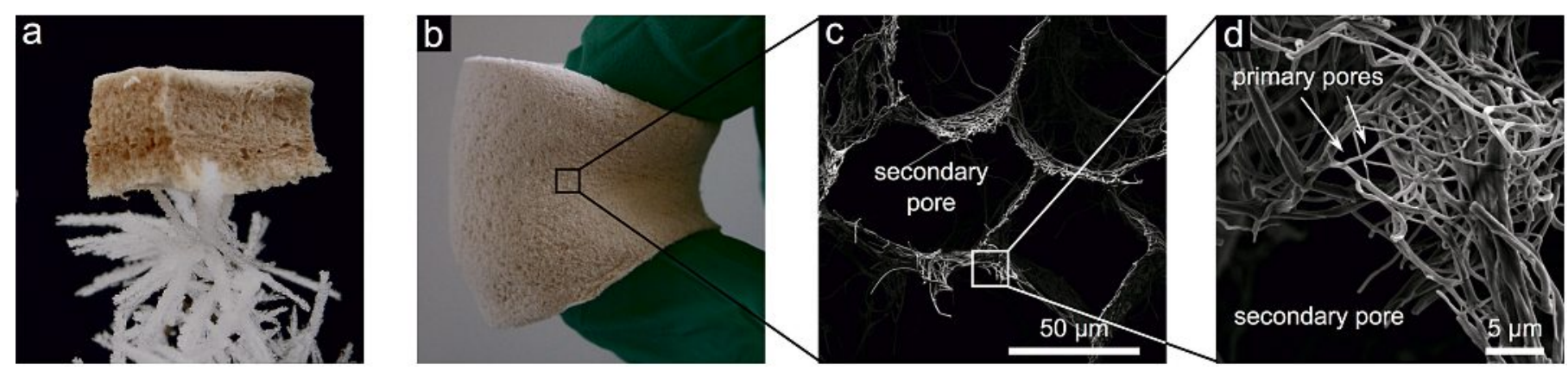

Fig. 1. Ultralight nanofiber-based aerogels supported by hoarfrost crystals (a). The fibrous pore walls enable high compressibility of the aerogel (b). The hierarchical pore architecture with major secondary (c) and minor primary pores (d) is clearly visible.

produced by electrospinning from a polymer solution (i). Using standard electrospinning, thin non-woven membranes are readily obtained. These membranes are subsequently cut in a non-dissolving liquid giving a homogenous dispersion of short nanofibers (ii). During freezing, the dispersed nanofiber fragments are rejected by and concentrated between the growing solvent crystals (iii). This natural entrapping or self-assembly process is crucial for the formation of the 3D architecture and determines its characteristics such as porosity and mechanic stability. By anisotropic cooling, directional solidification takes place and thus alignment of the pores is feasible. Finally, drying the frozen fiber dispersion by sublimation yields the desired raw body (iv). To ensure mechanical stability, the nanofiber-based aerogel is eventually crosslinked or it can be post-processed by using appropriate techniques.

\section{Electrospinning}

Preparing nanofibers by electrospinning is straightforward. The basic electrospinning setup consists of a high voltage power supply, a syringe pump to promote the polymer solution and a grounded collector. ${ }^{[7]}$ When high electric fields are applied to the surface of the polymer solution, surface charge is generated until the repulsive forces overcome the surface tension of the solution. This results in a thin jet of polymer solution, ejected from a so-called Taylor cone temporally formed at the tip of the syringe needle. As the jet dries during the flight, elongation by bending and whipping takes place until the dry fiber is deposited on the grounded collector with typical diameters between 50 and $500 \mathrm{~nm}$. Electrospun fibers are characterized by an ultra-high aspect and high surface-to-volume ratio. The majority of nanofibers used as aerogel framework was spun from synthetic polymers such as polyacrylic nitrile
(PAN), ${ }^{[2 a, b, 13 a, e-g]}$ polylactic acid (PLA) ${ }^{[13 i, j]}$ or polycaprolactone (PCL), ${ }^{[13 \mathrm{~h}]}$ but there are also composites reported from biopolymers or even from inorganic sources, such as gelatin, ${ }^{[13 i, j]}$ pullulan, ${ }^{[12]}$ or $\mathrm{SiO}_{2} \cdot{ }^{[13 b, c]}$

\section{Fiber Cutting}

To obtain a homogenous dispersion of short nanofibers, it is necessary to break the long electrospun nanofibers apart. By applying high shear forces it is indeed possible to untangle and cut the closely packed nonwovens. As exemplified, the water-soluble pullulan/polyvinyl alcohol (PVA) nanofibers are cut in 1,4-dioxane to obtain a stable fiber dispersion (Fig. 3a). The fiber fragment length is controlled by homogenization time. For a fiber length of approx. $40 \mu \mathrm{m}$ corresponding to an aspect ratio of 140 , a homogenization time of $20 \mathrm{~min}$ is sufficient. This exemplary aspect ratio for short pullulan/PVA nanofibers is fully in-line with literature findings for

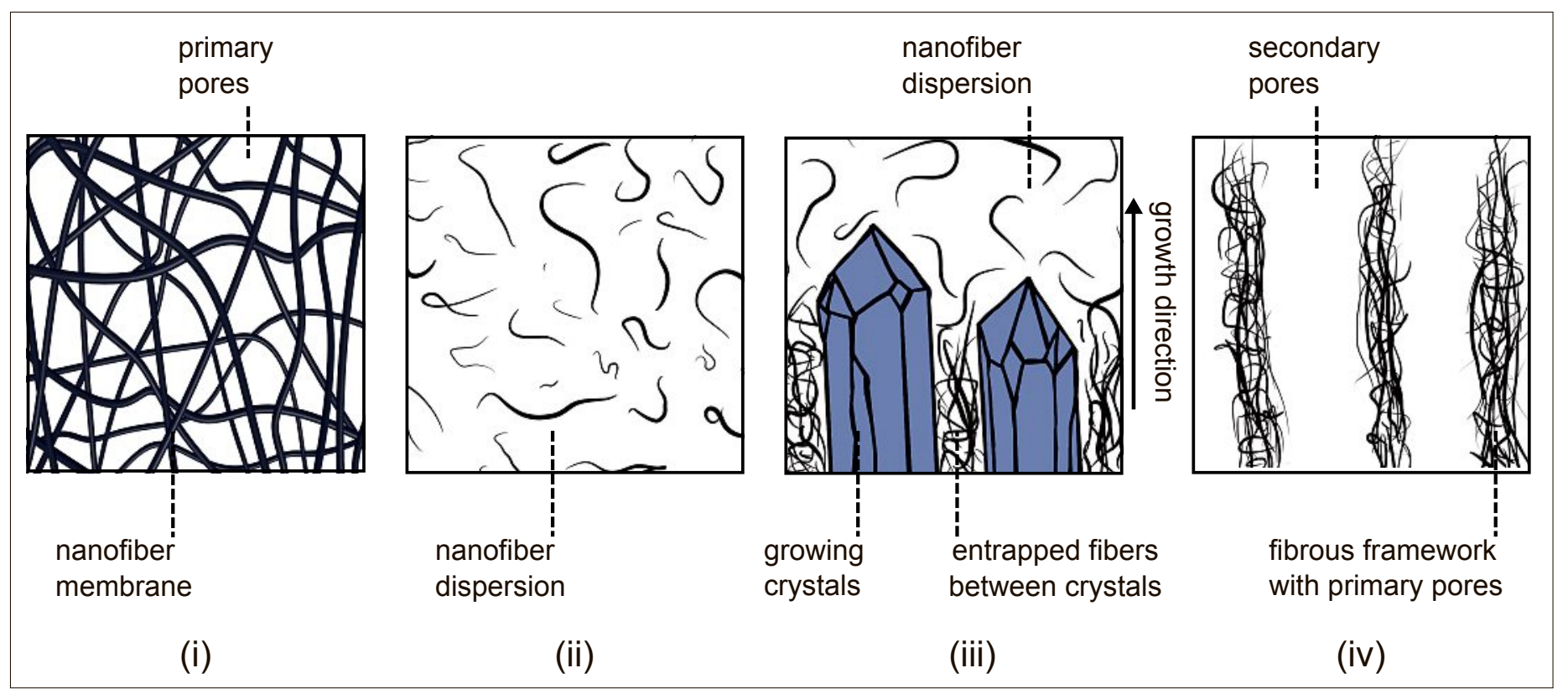

Fig. 2. The four main processing steps for nanofiber-based aerogels are: (i) fabrication of non-woven nanofibers by electrospinning, (ii) cutting of nanofibers to obtain dispersed short nanofibers, (iii) solid templating by freezing and (iv) drying by sublimation to obtain the 3D network of short nanofibers. 
Table 1. Current state of electrospun nanofiber based aerogels regarding materials, processing conditions, and applications.

\begin{tabular}{|c|c|c|c|c|c|c|c|}
\hline Fiber material & $\begin{array}{l}\text { Fiber aspect } \\
\text { ratio }\end{array}$ & $\begin{array}{l}\text { Dispersing } \\
\text { liquid }\end{array}$ & $\begin{array}{l}\text { Templating } \\
\text { temp. }\left[{ }^{\circ} \mathrm{C}\right]\end{array}$ & Crosslinking & Post processing & Application & Ref. \\
\hline $\begin{array}{l}\mathrm{PAN} \text { and } \mathrm{SiO}_{2} \\
\text { mixture }\end{array}$ & 80 & $\begin{array}{l}\text { water/ } \\
\text { tBuOH }\end{array}$ & -196 & $\begin{array}{l}\text { in situ } \\
\text { bifunctional } \\
\text { benzoxazine, (in } \\
\text { fiber) }\end{array}$ & pyrolysis & $\begin{array}{l}\text { thermal insulation, sound } \\
\text { absorption, emulsion } \\
\text { separation and electric } \\
\text { conduction }\end{array}$ & {$[2 \mathrm{a}]$} \\
\hline $\begin{array}{l}\mathrm{PAN} \text { and } \mathrm{SiO}_{2} \\
\text { mixture }+\mathrm{SiO}_{2} \\
\text { nanoparticles }\end{array}$ & 210 & camphene & approx. 0 & $\begin{array}{l}\text { in situ } \\
\text { bifunctional } \\
\text { benzoxazine, (in } \\
\text { dispersion) }\end{array}$ & none & $\begin{array}{l}\text { separation of oil/water } \\
\text { emulsions }\end{array}$ & [13a] \\
\hline $\mathrm{SiO}_{2}+\mathrm{KGM}^{\mathrm{a}}$ additive & $200^{\mathrm{b}}$ & water & $-196 /-78$ & $\begin{array}{l}\text { deacetylation of } \\
\text { KGM }\end{array}$ & pyrolysis & $\begin{array}{l}\text { electrical conductor, } \\
\text { pressure sensor } \\
\text { (wearable electronics) }\end{array}$ & [13b] \\
\hline $\mathrm{PVA} \mathrm{SiO}_{2}$ blend & $100-500$ & toluene & -196 & $\begin{array}{l}\text { polymer } \\
\text { deposition to } \\
\text { form core-shell } \\
\text { structure }\end{array}$ & none & organic dye removal & {$[13 c]$} \\
\hline \multirow{2}{*}{$\begin{array}{l}\text { poly(MA-MMA- } \\
\text { MABP)c/PAN blend }\end{array}$} & $120-150$ & dioxane & $\begin{array}{l}\text { not } \\
\text { reported }\end{array}$ & none & PVA coating & liquid uptake, cell growth & [2b] \\
\hline & 150 & dioxane & $\begin{array}{l}\text { not } \\
\text { reported }\end{array}$ & none & $\begin{array}{l}\text { PPX CVD } \\
\text { coating }\end{array}$ & $\begin{array}{l}\text { separation applications, } \\
\text { heat insulation }\end{array}$ & {$[13 d]$} \\
\hline $\begin{array}{l}\text { poly(2VP-co-MABP)d/ } \\
\text { poly(MA-MMA- } \\
\text { MABP)/PAN blend }\end{array}$ & 210 & dioxane & -20 & none & none & Au based catalysis & {$[13 e]$} \\
\hline PAN + GOe sheets & $80-120$ & water & -196 & pyrolysis & none & $\begin{array}{l}\text { electrical conductor, } \\
\text { super capacitor } \\
\text { electrode }\end{array}$ & {$[13 f]$} \\
\hline $\mathrm{PAN}+\mathrm{PI}^{\dagger}$ sheets & $80-120$ & water & -196 & pyrolysis & $\begin{array}{l}\text { in situ grow of } \\
\mathrm{MnO}_{2}\end{array}$ & $\begin{array}{l}\text { organic solvent } \\
\text { adsorbents, asymmetric } \\
\text { super capacitor }\end{array}$ & {$[13 g]$} \\
\hline PCL & -9 & $\mathrm{EtOH}$ & -196 & $\begin{array}{l}\text { thermally inducec } \\
\text { agglomeration wi }\end{array}$ & 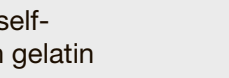 & bone tissue scaffold & [13h] \\
\hline \multirow{2}{*}{$\begin{array}{l}\text { gelatin/PLA } \\
\text { blend }\end{array}$} & 180 & $\begin{array}{l}\text { water/ } \\
\text { tBuOH }\end{array}$ & -196 & $\begin{array}{l}\text { in EtOH with } \\
\text { glutaraldehyde }\end{array}$ & $\begin{array}{l}\text { immersed in } \\
\text { L-glutamic acid } \\
\text { solution }\end{array}$ & $\begin{array}{l}\text { scaffold for tissue } \\
\text { engineering }\end{array}$ & [13i] \\
\hline & 180 & $\begin{array}{l}\text { water/ } \\
\text { tBuOH }\end{array}$ & -20 & $\begin{array}{l}\text { thermal and } \\
\text { carbodiimide }\end{array}$ & $\begin{array}{l}\text { treatment with } \\
\text { hyaluronic acid }\end{array}$ & cartilage tissue scaffold & {$[13 j]$} \\
\hline pullulan/PVA blend & 140 & dioxane & -80 to 7 & thermal & none & $\begin{array}{l}\text { aerosol filtration, tailoring } \\
\text { pore structure }\end{array}$ & [12] \\
\hline
\end{tabular}

${ }^{a}$ konjac glucomannan as additive; 'based on a fiber length of $50 \mu \mathrm{m}$; ' poly(methylacrylate-co-methyl methacrylate-co-4-methacryloyloxy-

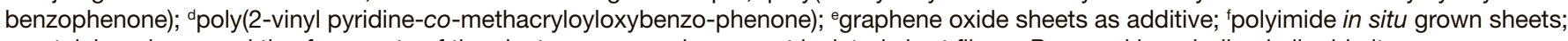
${ }^{9}$ Containing pieces and tiny fragments of the electrospun membrane, not isolated short fibers. Prepared by grinding in liquid nitrogen.

other polymers (Table 1).[2a,b,12,13] Fiber loading and the choice of dispersion liquid directly influence the solid templating process. To a certain extent, the choice of the polymeric framework restricts the option of usable dispersing liquids. Obviously, the dispersing liquid must not dissolve the suspended nanofibers. Yet, the liquid has to wet the fibers to enable the cutting process. Currently, water (partially augmented with alcohols as wetting agents), ethanol, tert-butyl alcohol, camphene, toluene, and 1,4-dioxane have been used as dispersing liquids. Moreover, the crystallographic properties of the selected dispersing liquid determine the architecture of the templated aerogel, i.e. lamellar with water, monoclinic with 1,4-dioxane or prismatic with tertbutyl alcohol.[12,13,14b]

\section{Solid Templating}

Once the dispersion or slurry of short nanofibers has been prepared, it is degassed and filled into a freezing mold. As the fiber dispersion is solidifying upon freezing, a natural segregation process takes place. When the solvent crystals grow slowly (i.e. heat sink temperature close to freezing point), the fibers inside the dispersion will be rejected and pushed away by the growing solvent crystals.[14a,b,15] If the velocity of the growing solvent crystals, the so-called freezing-front velocity, $v_{\mathrm{f}}$, becomes faster, then the fibers inside the dispersion cannot escape and they will be embedded in the growing crystals. Hence, an ultrafast $v_{\mathrm{f}}$ (i.e. shock freezing) will preserve the isotropic distribution of the short nanofibers from the starting dispersion, so that crystal templating is minimized. ${ }^{[12]}$ Depending on $v_{\mathrm{f}}$, on the fiber loading of the dispersion, and on the choice of solvent, pore size and structure can be governed, to tailor the macroscopic properties of the aerogel. ${ }^{[12,13 b, 14 a, b]}$ For instance using a directional freezing approach, it is possible to align the pores inside the aerogel.[16] These secondary pores can be tailored from $10-300 \mu \mathrm{m}$ by minutely controlling the freezing conditions such as freezing rate, dispersion liquid, and additives. Furthermore, by changing the fiber loading of the dispersion, the total porosity of solid templated aerogels can be modified. Typically, fiber loadings are between 0.1 and $40 \mathrm{mg} \mathrm{ml}^{-1}$, providing aerogels with respective densities between 0.12 and $140 \mathrm{mg} \mathrm{ml}^{-1}$ in the following freeze-drying step. Consequently, by carefully controlling both the fiber concentration and the freezing conditions, solid templating provides great flexibility in tailoring both the microstructure and the macrostructure of the aerogels' architecture.[2a,b,12,13] Although there is a lower limit for fiber loadings in the dispersion to prevent collapse of the nanofiber based structure upon freeze-drying, it is possible to prepare materials with porosities up to $99.992 \%$.[2a] 

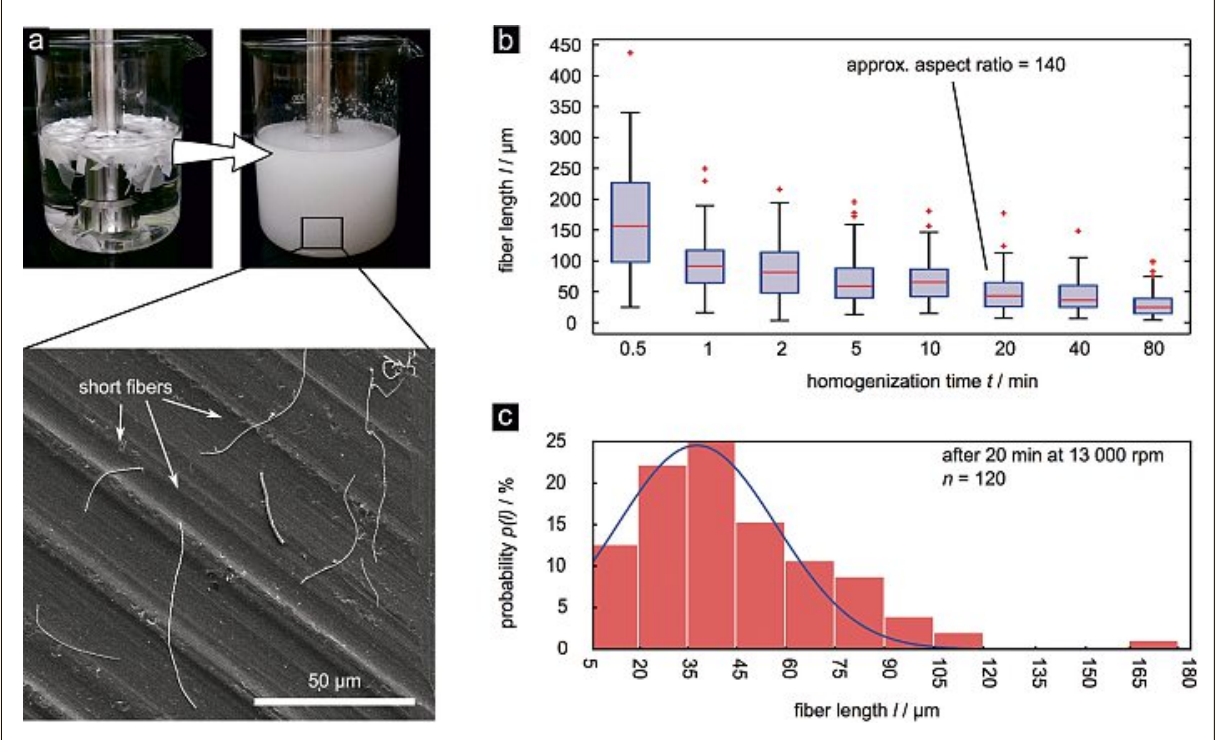

Fig. 3. Homogenization of electrospun nanofibers. (a) Photograph showing the cutting of nanofiber membrane fractions using a high-speed homogenizer and SEM image of short nanofibers (20 min homogenization time) after isolation. (b) Dependency of fiber length on homogenization time. (c) Histogram showing the fiber length distribution of the homogenized nanofibers after 20 min.

\section{Freeze-drying and Post-processing}

The frozen solvent crystals are removed by sublimation and only the nanofibrous framework is retained. The former nanofiber rich areas now become the cell walls, and the large, secondary pores $(10-300 \mu \mathrm{m})$ are a replica of the solvent crystals. Although the cell walls are thin, they show minor, primary pores $(2-5$ $\mu \mathrm{m})$ between tangled nanofibers. These primary pores are in the same size range as those of electrospun membranes.[17] This hierarchical and open-porous fibrous architecture has a tremendous relevance for potential applications such as tissue scaffolds, catalyst supports, sound absorption, or separation material (Table 1).

However, post processing of such ultralight structures is crucial. Most nanofiber-based aerogels are either chemically crosslinked or pyrolyzed to enhance their mechanical stability. Furthermore, there is progress in covering the fibers with an outer shell to form core-shell composites, thereby enhancing the framework's stability while sacrificing some porosity. This outer shell can be either polymeric (e.g. poly(p-xylylene), PPX) or inorganic (e.g. $\left.\mathrm{MnO}_{2}\right) \cdot{ }^{[13 \mathrm{~d}, \mathrm{~g}]}$ Post surface modifications add a further dimension of versatility to nanofiber-based aerogels and many recipes can be transferred from proven procedures applied to electrospun nanofiber membranes. Without losing the intrinsic fibrous characteristics prior to solid templating, it is possible to adapt knowledge from the past two decades of electrospinning and literally turn it into the third dimension.

\section{Current State of Applications}

Already electrospun membranes have become interesting scaffolds for tissue engineering, since nanofibers can mimic the structural and biological functions of the extracellular matrix. ${ }^{[18]}$ Therefore, 3D solid-templated structures with an openporous and hierarchical architecture offer even further possibilities and prove to be very similar to natural structured materials, such as bone or sponges. ${ }^{[2,13 \mathrm{~h}-\mathrm{j}]}$ Chen et al. showed that L-929 cells grow, proliferate, and infiltrate into gelatin/poly(Llactide)-based aerogels. [13i] In optimizing the crosslinking conditions, Chen et al. were able to cultivate chondrocytes on an improved gelatin/PLA aerogel. These new scaffolds were also subject to an in vitro study on rabbits and showed promising properties for cartilage tissue engineering application. ${ }^{[13 j]}$ By exploiting the morphological similarity to bone, Xu et al. reported that electrospun PCL 3D aerogels promote growth of mouse bone marrow mesenchymal stem cells (mBMSC) acting as a promising scaffold for functional bone regeneration through the physiological endochondral ossification process. ${ }^{[13 \mathrm{~h}]}$ Using a simple PVA coating, Duan et al. were able to colonize Jurkat cells on the formerly hydrophobic poly(MA-MMA-MABP)/ PAN aerogel. ${ }^{[2 b]}$ Further developments in using such hierarchically structured aerogels can be expected in the near future.

Solid-templated nanofiber-based materials reveal high flexibility and reversible compressibility. Responsible for this behavior may be the robust hierarchical cellular structure and the fibers' character- istic entanglement. $[2 \mathrm{a}, 12,13 \mathrm{~b}]$ This stands in contrast to ceramic aerogels with similar functions, which are usually very brittle and break under strain. ${ }^{[19]}$ In exploiting the unique morphology, high porosity, large surface area, ultralight weight and interconnected network the broad scope of nanofiber based aerogels was shown. Si et al. enhanced the aerogels' usability by adding $\mathrm{SiO}_{2}$ fibers or $\mathrm{SiO}_{2}$ nanoparticles. The generated aerogels proved to be very efficient in separating oil from water.[2a,13a] Furthermore they showed beneficial sound absorption properties and the materials could also act as a thermal insulator.[2a] In their most recent study $\mathrm{Si}$ et al. demonstrated that biopolymer-based aerogels might act as wearable pressure sensors upon pyrolysis. ${ }^{[13 \mathrm{~b}]} \mathrm{Kim}$ et al. used a blend of $\mathrm{PVA} / \mathrm{SiO}_{2}$ fibers with a triethynylbenzene based polymeric shell to selectively remove organic dye from water.[13c] Lai et al. pyrolyzed PAN and polyimide sheet (PI) based aerogels, which were successively modified by an in situ grown shell-layer of $\mathrm{MnO}_{2}$ to act as organic solvent absorber or as an asymmetric super capacitor. ${ }^{[13 \mathrm{~g}]}$ An electrically conductive material was obtained by Huang et al. when pyrolyzing a PAN and graphene oxide sheet (GO) based aerogel. This material showed promising hydrogen evolution reaction activity.[13f] Duan et al. immobilized Au nanoparticles on the surface of nanofibers prior to solid templating. The obtained Au-loaded aerogel featured high catalytic activity in reducing nitrophenols, while the aerogels themselves could be used several times. The high porosity of the catalysts' support allows an efficient mass transport with reaction rates equal to dispersed systems. [13e] Our current research aims to understand the pore formation mechanism to take advantage of the possibility to tune the pore size and architecture of the aerogels. We were able to tailor the size of secondary pores between 9.5 and $123 \mu \mathrm{m}$, thus directly increasing the mass flow through the aerogel by a factor of 7 . At the same time it was possible to lower aerosol penetration from 9.98 to $0.04 \%$ by altering the aerogels' microstructure to enhance the filtration efficiency by more than two orders of magnitude. ${ }^{[12]}$

\section{Perspectives}

After a promising start, solid templating of electrospun materials may become established as a new process to generate tailor-made 3D structures for three reasons: first, the process is simple and straightforward. Liquid handling of fibrous dispersions is scalable and, most importantly, independent from the fiber formation process by electrospinning. Second, since the 
fibrous character is maintained within the aerogel, all the expertise and inspiration generated for electrospun fibers can be transferred. A stunning number of electrospun nanofibers with different polymers and properties are fabricated and published each year. So far, only a tiny fraction of them are processed into aerogels. Third, the underlying freezing mechanism is very similar to the proposed mechanism in freeze-casting of ceramic nanoparticles providing an excellent knowledge base of developments and limitations. [14a,b,16,20] Although the toolbox for synthesizing new fibrous aerogels is well equipped, it is obvious that this young field of research is still in its infancy. Many fundamental questions and a number of aspects in processing short nanofibers are still waiting to be resolved and understood. Yet, further work on, for example, pore alignment and gradients within the aerogel, improvement in mechanical properties, complex material composites and development of largescale production is expected.

\section{Acknowledgements}

F. D. thanks DSM and the Swiss Chemical Society for the SCS-DSM award. This work was supported by Forschungsfond Aargau, IVF-Hartmann AG (Thesis of F. D.), and COST ACTION MP1206 (travel grants).

Received: January 25, 2017

[1] a) P. Alonso-Gonzalez, A. Y. Nikitin, F. Golmar, A. Centeno, A. Pesquera, S. Velez, J. Chen, G. Navickaite, F. Koppens, A. Zurutuza, F. Casanova, L. E. Hueso, R. Hillenbrand, Science 2014, 344, 1369; b) Z. Chen, Nat. Mater. 2011, 10, 424; c) C. Minas, D. Carnelli, E. Tervoort, A. R. Studart, Adv. Mater. 2016, 28, 9993; d) X. Wang, Y. Zhang, C. Zhi, X. Wang, D. Tang, Y. Xu, Q. Weng, X. Jiang, M. Mitome, D. Golberg, Y. Bando, Nat. Commun. 2013, 4, 2905; e) M. Yamaguchi, M. Shiga, H. Kaburaki, Science 2005, 307, 393; f) C. Zhu, T. Y.-J. Han, E. B. Duoss, A. M. Golobic, J. D. Kuntz, C. M. Spadaccini, M. A. Worsley, Nat. Commun. 2015, 6, 1; g) M. Langner, S. Agarwal, A.
Baudler, U. Schroder, A. Greiner, Adv. Funct. Mater. 2015, 25, 6182.

[2] a) Y. Si, J. Yu, X. Tang, J. Ge, B. Ding, Nat. Commun. 2014, 5, 5802; b) G. G. Duan, S. H. Jiang, V. Jerome, J. H. Wendorff, A. Fathi, J. Uhm, V. Altstadt, M. Herling, J. Breu, R. Freitag, S. Agarwal, A. Greiner, Adv. Funct. Mater. 2015, 25, 2850; c) S. Chabi, V. G. Rocha, E. Garcia-Tunon, C. Ferraro, E. Saiz, Y. Xia, Y. Zhu, ACS Nano 2016, 10, 1871; d) C. Ferraro, E. García-Tuñón, V. G. Rocha, S. Barg, M. D. Fariñas, T. E. G. Alvarez-Arenas, G. Sernicola, F. Giuliani, E. Saiz, Adv. Funct. Mater. 2016, 26, 1636; e) X. Gui, J. Wei, K. Wang, A. Cao, H. Zhu, Y. Jia, Q. Shu, D. Wu, Adv. Mater. 2010 , 22 , 617; f) N. Kranzlin, M. Niederberger, $A d v$. Mater. 2013, 25, 5599; g) F. Rechberger, M. Niederberger, Nanoscale Horizons 2017, 2, 6.

[3] a) B. Sun, X.-J. Jiang, S. Zhang, J.-C. Zhang, Y.-F. Li, Q.-Z. You, Y.-Z. Long, J. Mater. Chem. $B$ 2015, 3, 5389; b) B. Sun, Y. Z. Long, H. D. Zhang, M. M. Li, J. L. Duvail, X. Y. Jiang, H. L. Yin, Prog. Polym. Sci. 2014, 39, 862.

[4] a) G. Chang, X. Zhu, A. Li, W. Kan, R. Warren, R. Zhao, X. Wang, G. Xue, J. Shen, L. Lin, Mater. Des. 2016, 97, 126; b) X. Guo, Y. Yao, T. Zhou, R. Xiang, M. Chen, J. Appl. Polym. Sci. 2015, 133, 43003; c) B. Sun, Y.-Z. Long, F. Yu, M.-M. Li, H.-D. Zhang, W.-J. Li, T.-X. Xu, Nanoscale 2012, 4, 2134.

[5] M. Simonet, O. D. Schneider, P. Neuenschwander, W. J. Stark, Polym. Eng. Sci. 2007, 47, 2020.

[6] J. Jiang, M. A. Carlson, M. J. Teusink, H. Wang, M. R. MacEwan, J. Xie, ACS Biomater. Sci. Eng. 2015, 1, 991 .

[7] a) W. E. Teo, S. Ramakrishna, Nanotechnology 2006, 17, R89; b) J. H. Wendorff, S. Agarwal, A. Greiner, 'Electrospinning: Materials, Processing, and Applications', Wiley-VCH, Weinheim, 2012; c) A. Greiner, J. H. Wendorff, Angew. Chem. Int. Ed. 2007, 46, 5670; d) R. Buttiker, J. Ebert, C. Hinderling, C. Adlhart, Chimia 2011, 65, 182.

[8] J. Rnjak-Kovacina, A. S. Weiss, Tissue Eng., Part B 2011, 17, 365.

[9] J. S. Kim, D. H. Reneker, Polym. Compos. 1999, 20, 124

[10] a) I. Greenfeld, E. Zussman, J. Polym. Sci., Part B: Polym. Phys. 2013, 51, 1377; b) I. W. Fathona, A. Yabuki, Curr. Appl. Phys. 2014, 14,761 ; c) I. W. Fathona, A. Yabuki, J. Mater. Process. Technol. 2013, 213, 1894.

[11] a) M. Thieme, S. Agarwal, J. H. Wendorff, A. Greiner, Polym. Adv. Technol. 2009, DOI: 10.1002/pat.1617; b) S. Jiang, G. Duan, J. Schöbel, S. Agarwal, A. Greiner, Compos. Sci. Technol. 2013, 88, 57; c) M. Langner, A. Greiner, Macromol. Rapid Commun. 2016, 37,
351; d) Y. Ren, S. Wang, R. Liu, J. Dai, X. Liu, J. Yu, $R S C A d v$. 2016, 6, 30139; e) Y. Yu, S. Hua M. Yang, Z. Fu, S. Teng, K. Niu, Q. Zhao, C. Yi, $R S C A d v$. 2016, 6, 110557.

[12] F. Deuber, S. Mousavi, M. Hofer, C. Adlhart, ChemistrySelect 2016, 1, 5595.

[13] a) Y. Si, Q. Fu, X. Wang, J. Zhu, J. Yu, G. Sun, B. Ding, ACS Nano 2015, 9, 3791; b) Y. Si, X. Wang, C. Yan, L. Yang, J. Yu, B. Ding, Adv. Mater. 2016, 28, 9512; c) J. G. Kim, T. J. Choi, J. Y. Chang, Chem. Eng. J. 2016, 306, 242 ; d) G. G. Duan, S. H. Jiang, T. Moss, S. Agarwal, A. Greiner, Polym. Chem. 2016, 7, 2759; e) G. Duan, M. Koehn-Serrano, A. Greiner, Macromol. Rapid Commun. 2017, 38, 1600511; f) Y. Huang, F. Lai, L. Zhang, H. Lu, Y. E. Miao, T. Liu, Sci. Rep. 2016, 6, 31541; g) F. Lai, Y. Huang, L. Zuo, H. Gu, Y.-E. Miao, T. Liu, J. Mater. Chem. A 2016, 4, 15861; h) T. Xu, J. M. Miszuk, Y. Zhao, H. Sun, H. Fong, $A d v$. Healthcare Mater. 2015, 4, 2238; i) W. Chen, J. Ma, L. Zhu, Y. Morsi, H. EI-Hamshary, S. S. AlDeyab, X. Mo, Colloids Surf., B 2016, 142, 165; j) W. Chen, S. Chen, Y. Morsi, H. El-Hamshary, M. El-Newhy, C. Fan, X. Mo, ACS Appl. Mater. Interfaces 2016, 8, 24415.

[14] a) S. Deville, Adv. Eng. Mater. 2008, 10, 155 ; b) S. Deville, E. Saiz, R. K. Nalla, A. P. Tomsia, Science 2006, 311, 515; c) J. Buschmann, E. Müller, P. Luger, Acta Crystallogr. Sect. C: Cryst. Struct. Commun. 1986, 42, 873; d) R. Asthana, S. N. Tewari, J. Mater. Sci. 1993, 28, 5414.

[15] a) U. G. K. Wegst, M. Schecter, A. E. Donius, P. M. Hunger, Philos. Trans. R. Soc. London, Ser. A 2010, 368, 2099; b) S. Deville, Materials 2010, 3, 1913.

[16] Y. Zhou, S. Fu, Y. Pu, S. Pan, A. J. Ragauskas, Carbohydr. Polym. 2014, 112, 277.

[17] a) D. Li, M. W. Frey, Y. L. Joo, J. Membr. Sci. 2006, 286, 104; b) Z.-M. Huang, Y. Z. Zhang, M. Kotaki, S. Ramakrishna, Compos. Sci. Technol. 2003, 63, 2223.

[18] Q. P. Pham, U. Sharma, A. G. Mikos, Tissue Eng. 2006, 12, 1197.

[19] a) X. Y. Zheng, H. Lee, T. H. Weisgraber, M. Shusteff, J. DeOtte, E. B. Duoss, J. D. Kuntz, M. M. Biener, Q. Ge, J. A. Jackson, S. O. Kucheyev, N. X. Fang, C. M. Spadaccini, Science 2014, 344, 1373; b) J. Seuba, S. Deville, C. Guizard, A. J. Stevenson, Sci. Technol. Adv. Mater. 2016 , 17, 313; c) J. Seuba, S. Deville, C. Guizard, A. J. Stevenson, Sci. Rep. 2016, 6, 24326.

[20] a) T. Fukasawa, Z. Y. Deng, M. Ando, T. Ohji, Y. Goto, J. Mater. Sci. 2001, 36, 2523; b) K. Araki, J. W. Halloran, J. Am. Ceram. Soc. 2005, 88 , 1108 ; c) N. O. Shanti, K. Araki, J. W. Halloran, J. Am. Ceram. Soc. 2006, 89, 2444; d) W. L. Li, K. Lu, J. Y. Walz, Int. Mater. Rev. 2013, 57, 37. 